Маја Ђукановић

Борко Ковачевић

Универзитет у Београду

Филолошки факултет
316.66-054.6

371.3:81'25

https://doi.org/10.18485/climb.2017.5.1.ch5

\title{
О ПРЕВАЗИЛАЖЕЊУ КУЛТУРНИХ РАЗЛИКА У НАСТАВИ СТРАНОГ ЈЕЗИКА
}

\section{Сажетак}

Рад се бави представљањем неких проблема и изазова у настави страног језика у мултикултурном контексту. Први пример су запажања стечена током рада са страним студенатима који су учили српски језик у оквиру пројекта Свет у Србији. У питању су студенти из различитих земаља и различитих култура, чији матерњи језици припадају различитим језичким породицама. Други пример је настава словеначког као страног језика за имигранте, односно припаднике националне мањине. Рад упућује на неке социокултурне разлике које могу да доведу до грешака или неразумевања у комуникацији.

Кључне речи: настава страног језика, мултикултурни контекст, српски језик, словеначки језик

\section{1. Увод}

Под учењем језика се углавном подразумева лингвистички ниво, односно вербална продукција садржаја на језику који се учи. Врло често се пренебрегава чињеница да језик није само пуко средство за размјену информација и комуникацију, него је повијесни организам, одређен друштвеним, културним (и политичким) чимбеницима, и као такав он је дио етничке, културне или неке друге групне припадности (Пришл 2005: 69). 
Колико су језик и култура испреплетани најбоље показују савремени уџбеници страних језика у којима се скоро у свим тематским јединицама, поред језичке грађе (лексике и граматике), инфилтрирају и обичаји, навике, традиција земље домаћина, али се све то и повезује са земљом студента кроз вежбе комуникације. У последње време све се чешће указује на то да је настава страног језика одговарајући наставни систем за планско праћење и освешћивање интеркултурних разлика, и то језичко-изражајних и понашајних. Таква настава доследно потврђује кључно начело комуникативног приступа у процесу наставе страног језика - да је основни циљ наставе страног језика постизање комуникацијске компетенције у друштвеној интеракцији са страним говорником (Чеброн 2005: 91).

Поменуте културне разлике долазе до изражаја још више уколико се настава одвија у мултикултурном контексту, где постоје две линије различитости. Прво, културна позадина језика који се предаје у односу на све друге различите културне базе студената. И друго, различитост између културних образаца самих студената, ученика неког страног језика, који долазе из различитих земаља и култура. Управо такав случај је у два примера који се обрађују у овом раду: настава српског језика као страног у програму Cвет у Србији и настава словеначког језика као страног за имигранте, односно припаднике националне мањине.

\section{2. Српски као страни језик у програму Свет у Србији}

Филолошки факултет у Београду организовао је током последњих неколико година наставу српског језика за стране студенте, учеснике пројекта Свет у Србији, стипендисте Владе Републике Србије. Пројекат је подразумевао да студенти овладају српским језиком до нивоа потребног за праћење наставе на факултету, а затим да упишу неки од факултета Београдског универзитета, основне, мастер или докторске студије. Предуслов за учествовање у овом пројекту био је завршена најмање средња школа (за упис на основне студије) или (за мастер или докторске студије) завршен факултет чији је програм могуће нострификовати од стране наших образовних институција. 
Култура и/или наука

Етнички састав студената био је врло разноврстан и управо је та разноврсност била велики изазов, како за предаваче, тако и за студенте, али и одлична база за упознавање различитих језика, култура, обичаја и навика. Већина студената је била из нама егзотичних земаља са којима до сада нисмо имали честих или никаквих контаката, док смо са некима од њих имали у ранијим периодима врло живу сарадњу:

- Латинска Америка и Кариби:

Мексико, Бразил, Боливија, Еквадор, Тринидад и Тобаго, Гренада, Антигва и Барбуда, Јамајка

- Африка:

Египат, Тунис, Мароко, Мали, Гана, Нигерија, Руанда, Бурунди, Кенија, Танзанија, Уганда, Јужноафричка Република, Зеленортска острва, Гвинеја, Конго, Замбија, Зимбабве, Намибија, Ангола, Мозамбик, Судан, Габон, Сејшели, Етиопија

- Азија:

Шри Ланка, Индонезија, Бангладеш, Вијетнам, Монголија

- Блиски исток:

Палестина, Иран, Ирак, Сирија, Либан

С обзиром на толики број различитих земаља, различитих религија (ислам и хришћанство у комбинацији са локалним религијама), као и различитих матерњих језика из различитих језичких породица, врло јасно су се искристалисали и различити лингвокултуролошки модели. ${ }^{1}$

Од почетног контакта са студентима, али и током наставних и испитних активности, уочени су одређени обрасци и разлике у понашању међу представницима различитих култура. ${ }^{2}$

Најдисциплинованији и најумеренији у понашању били су студенти из подсахарске Африке и са Далеког истока. Увек су испољавали дистанцираност и званичност према предавачима, а током испитних активности стриктно су поштовали предвиђена правила. Са друге стране, студенти са Блиског истока показивали су потребу за

1 О програму Cвет у Србији и неким запажањима која су настала као резултат рада са страним студентима говори се и у Крајишник и Ковачевић (2013) и Ковачевић и Крајишник (2015).

2 Ови обрасци и разлике преузимају се из Крајишник и Ковачевић (2013), где су културна запажања током рада на пројекту Свет у Србији представљена детаљније. 
већом, често и претераном комуникацијом са предавачима. Ова комуникација је неретко задирала и у приватне сфере, како за време часова, тако и ван њих. За време полагања испита ови студенти су често прибегавали недозвољеним активностима.

Како је процес усвајања језика одмицао, тако су се повећавале и могућности за развијање све богатије и разноврсније комуникације између предавача и студената. Задајући студентима често провокативне теме на часовима конверзације, могло се издвојити неколико модела културолошког типа:

1) Ортодоксни муслимани не прихватају разговоре о савременим друштвеним односима: положај жена, родна равноправност, глобализација друштвеног система и слично.

2) Студенти са Блиског истока имају строге стереотипе о већини културних, историјских, социјалних и религијских релација у друштву, без компромиса. Тврде да је њихова земља најбоља и најлепша земља. Једина исправна политика је политика њихових земаља, где се једе и најбоља храна. Ислам је према њима најбоља религија.

3) Студенти из подсахарских и карипских земаља спремни су на разговор о свим темама. За разлику од студената са Блиског истока, њихов однос према домовини, као и другим друштвеним темама, умерено је патриотски и критички. Оно што у њиховом случају упада у очи јесте идеализована слика бивших колонизатора (Енглеска, Француска, Белгија...), као и Сједињених Америчких Држава. Западни свет је према њима идеал коме треба тежити.

Културне разлике често доводе до проблема у језичкој комуникацији. Увежбавајући лексику породичних односа, студенти су добили питање како им се зову поједини чланови породице и чиме се баве. На једноставно питање „Како се зове твоја мама?“, студент из Малија одговара: „Која?“. Предавач, мислећи да студент не разуме, понавља питање полако, разговетно и уз употребу геста. Добија исти одговор - питање. Резултат ове конверзације: збуњени и предавач и студент. Разумевање је уследило након студентовог одговора (на српском језику) да у Малију међу муслиманским становништвом владају полигамни закони те да он има четири маме и рекао је имена за све четири.

Покушавајући да објасни семантичку синонимију облика плашим се, бојим се и страх ме је и њихову рекцију са генитивом, предавач је сваког студента питао: „Чега се плашите (бојите)?“ или „Чега 
Култура и/или наука

вас је страх?“. Одговори су углавном били очекивани: змије, лава, Бога, смрти, професора, болести итд. Међутим, код неколицине студената, сви из Јужноафричке Републике, одговор је био исти: жабе! Знајући да жаба у европском миљеу не представља неку опасну животињу (више изазива осећање гађења, непријатности, али не и страха), предавач претпоставља грешку у комуникацији узроковану неразумевањем лексичког садржаја од стране студената. Додатним објашњењем сазнаје се међутим да у Јужноафричкој Републици живе велике, отровне жабе које улазе у куће и којих се становништво јако плаши.

\section{3. Словеначки као страни језик за националну мањину и имигранте}

Центар за словеначки као други и страни језик при Филозофском факултету у Љубљани има веома развијене различите програме за учење тог језика. Поред наставе словеначког на великом броју универзитета широм света, одговарајући органи Републике Словеније посвећују велику пажњу настави словеначког језика као страног у иностранству (Ђукановић 2014а, 2014б). У вези са мултикултурним контекстом наставе страног језика, посебно су занимљиви курсеви за словеначку националну мањину из дијаспоре, као и посебни течајеви за имигранте у Словенију. ${ }^{3}$

Што се тиче курсева за Словенце (по пореклу) из дијаспоре, треба имати у виду да су то углавном људи који слабо или нимало знају словеначки језик и да долазе из различитих делова света, из различитих земаља и културног окружења. Са једне стране, ту су полазници ових курсева којима су словеначки језик и култура блиски (на првом месту друге словенске земље), али са друге стране, и људи који долазе из тотално различитих језичких и културних окружења (људи из Аустралије, Аргентине, Бразила и других земаља). Оно по чему се иначе успешна делатност Центра за словеначки као други и страни језик посебно истиче (рецимо у поређењу са ситуацијом у настави српског као страног језика) јесте постојање уџбеника и другог наставног материјала посебно прилагођеног различитим полазницима курсева, у зависности од њиховог лингвокултурног порекла. Кон-

3 Детаљније о овим течајевима на: http://centerslo.si/za-otroke/projekti/migranti/. 
кретно, у случају ових курсева за Словенце из дијаспоре, праве се посебне групе полазника, где се користе различити, њима прилагођени уџбеници и друга наставна средства.

Словенија је последњих неколико деценија била дестинација у коју су у потрази за послом одлазили многи људи из некадашњих југословенских република. У скорије време присутна је и имиграција из неких других земаља, попут Албаније, али и неких источних земаља (Турци, Арапи, Кинези...).

Досељеници из југословенских република (данас посебних држава) одувек су били посебан слој становништва, у социокултурном, па наравно и језичком смислу. Док су Словенија и друге републике бивше Југославије били једна држава, потреба за интеграцијом у словеначко друштво није била толико изражена и знање словеначког језика није био посебно истицан циљ (наравно у зависности од занимања). Откако се ради о различитим земљама, та потреба за културном и језичком интеграцијом је наравно постала израженија и имигранти из бивших југословенских репблика су се нашли пред ситуацијом да морају да уче словеначки језик (више и официјелније него раније). Као резултат тог процеса учења словеначког језика код ових имиграната се ствара и један посебан идиом, који карактерише настојање да се очува њихов различит национални идентитет. Иако се савладава словеначки као страни језик, чува се ипак посебна (српскохрватска) лексика. Та српско-хрватска лексика у неким сферама продире и у словеначки језик, у смислу да је користе Словенци. Ту су посебно занимљиви неки примери не баш престижне лексике, као што су на пример псовке. То свакако даје још јачу негативну социокултурну конотацију према овој групи имиграната међу Словенацима.

Посебно занимљиво место у оквиру усвајања елемената културе представљају родбински термини. Познато је да у различитим језицима различит степен пажње се посвећује различитим родбинским односима, у зависности од културних одлика друштва које се служи одређеним језиком. ${ }^{4}$ Тако на пример и српски и словеначки језик, иако веома слични и наравно генетски блиски, имају неке разлике у родбинским терминима, које могу бити проблем приликом учења словеначког језика. Тако су словеначком термину brat еквиваленти у

4 Генерално о родбинским терминима в. нпр. Ален (1989), а конкретно везано за словеначки језик Ђукановић (2011). 
Култура и/или наука

српском језику брат, рођени брат, брат од стрица, брат од тетке, брат од ујака. Словеначки bratranec је српски брат од стрица, брат од тетке, али и брат од ујака. Исто тако словеначки термин sestra одговара српским терминима сестра, рођена сестра, сестра од стрица, сестра од тетке, сестра од ујака, а термин sestrična терминима сестра од стрица, сестра од тетке, сестра од ујака.

\section{4. Закључак}

Наведене тешкоће у савладавању страног језика отварају бројна питања са подручја лингводидактике, социолингвистике, лексикологије и бројних других научних дисциплина. Њиховом решавању се треба интензивно посветити, јер се једино на тај начин могу, макар делимично, превазићи тешкоће које настају услед међукултурних разлика између говорника различитих језика и носилаца различитих култура.

Може се закључити да је у настави неког страног језика од изузетног значаја имати у виду културне разлике. Поготово ако се ради о настави у мултикултурном контексту. Како разлике између културног модела коме припада језик који се учи и културног модела коме припадају студенти, тако и између различитих културних модела чији су представници сами студенти.

У ситуацији када су студенти различитог етничког и културног порекла, најбољи се резултати постижу интерактивним приступом, а пре свега стварањем атмосфере интеркултурализма. Предавачи морају да поседују одговарајућу комуникацијску спретност која подразумева интеракцију између студената различитих култура. Сажето речено, настава страног језика мора се ускладити са потребама студената којима се предаје, односно наставу страног језика треба адаптирати према културном моделу коме студенти припадају.

\section{Литература}

Allen, N.J. „The evolution of kinship terminologies”. Lingua 77 (1989): 173-185.

Đukanović, Maja. „Svakovega tasta sestrična je moja mala teta“. V. Smole (ur.). Družina v slovenskem jeziku, literaturi in kulturi. Zbornik 47. Ljubljana: Univerza v Ljubljani, 
Filozofska fakulteta, Oddelek za slovenistiko, Center za slovenščino kot drugi/tuji jezik. (2011): 29-37.

Đukanović, Maja. „Slovenščina v Srbiji: preteklost, sedanjost in prihodnost“. Hotimir

Tivadar (ur.). Prihodnost slovenščine in slovenistik po svetu. 50. SSJLK. Ljubljana: Znanstvena založba Filozofske fakultete. (2014a): 177-184.

Đukanović, Maja. ,PPouk slovenskega jezika in kulture v Srbiji“. Alenka Doležalová-

Jensterle, Jansa Honzak Jahič, Andrej Šurla (ur.). Sto let slovenistiky na Univerzite Karlove $v$ Praze: pedagogove a vedci ve stinu dejin. Vyd. 1. Praha: Filozoficka fakulteta Univerzity Karlovy. (20146): 405-411.

Ковачевић, Б. и Крајишник, В. „Нека лингвокултуролошка запажања у настави српског као страног језика". ВеснаПоловина и Снежана Гудурић (ур.). Примењена лингвистика данас-изазови модерног доба. Београд: Друштво за примењену лингвистику Србије, Филолошки факултет у Београду и Филозофски факултет у Новом Саду, 2015: 135-140.

Крајишник, В. и Ковачевић Б. „Утицај културних разлика на језичку комуникацију у настави српског као страног језика". Љ. Бајић (ур.). Култура: у потрази за новом парадигмом. Књига 3. Београд: Филолошки факултет, 2013: 43-52.

Пришл, Е. „Вербална и невербална интеркултурална комуникација”. Из: Без предрасуда и стереотипа. Ријека: Издавачки центар Ријека, 2005.

Чеброн, Н. „Увођење интеркултуралних елемената у наставу страног језика с нагласком на енглескоме ка лингви франци". Из: Без предрасуда и стереотипа. Ријека: Издавачки центар Ријека, 2005.

\section{Maja Đukanović \\ Borko Kovačević}

\section{ON OVERCOMING CULTURAL DIFFERENCES IN TEACHING A FOREIGN LANGUAGE}

\section{Summary}

This paper discusses some issues in teaching a foreign language in a multicultural context. The first example is related to some remarks that have been noticed during the work with the students who learned Serbian in the project Svet u Srbiji (The World in Serbia). The participants of the project were students from different countries and different cultures, whose native languages belong to different language families. The second example is related to teaching Slovenian to immigrants and to the members of the national minority. The research emphasizes some sociocultural differences that can bring to mistakes or misunderstanding in communication. 